\title{
Producer's Self-Declared Wind Energy ECO-Labeling Consequences on the Market: A Canadian Case Study
}

\author{
Clare D'Souza ${ }^{1, *}$ and Emmanuel K. Yiridoe ${ }^{2}$ \\ 1 School of Business, Entrepreneurship, Innovation and Marketing, La Trobe University, Bundoora, \\ Victoria 3083, Australia \\ 2 Department of Business \& Social Sciences, Faculty of Agriculture, Dalhousie University, Truro, NS B2N 5E3, \\ Canada; emmanuel.yiridoe@dal.ca \\ * Correspondence: cdsouza@latrobe.edu.au
}

Received: 14 January 2019; Accepted: 22 February 2019; Published: 26 February 2019

check for updates

\begin{abstract}
The demand for environmental labels is increasingly becoming important for consumers to differentiate products and to make an informed choice. This study reports the findings of a business case study in Nova Scotia (Canada) that demonstrates how renewable wind energy and wind labeling can extend the competitive advantage of a producer. By using qualitative case study techniques, the study generates evidence which suggests on the firm level that wind energy and labelling influences competitive advantage of firms, can dictate a premium price, can differentiate products, yet achieve a low-cost advantage. Wind labels also have the potential to drive the supply chain's environmental value to the consumer as the end user by requiring the distribution chain to follow good environmental practices. On the consumer level, in terms of label information, whereby product qualities cannot be evaluated by a search prior to purchase or by experience after purchase, eco-friendliness of the product can take predominance. Not all consumers will buy eco-friendly eggs; instead, there are other factors that drive consumers, such as their opinions towards wind technology, consumer psychographics, personality, and other behavioural determinants and, hence, attract a strong niche market. Finally, for the trust in labels, though the producer does not have third party accreditation, the labels work for them, through the means-end chain analysis where egoistic and altruistic intentions persuade environmental behaviour. As such, this study highlights the probability that in principle, there appears to be an opportunity for wind labelling to be successful; in practice, wind labelling is bound to attract a particular niche market through differentiation strategies.
\end{abstract}

Keywords: environmental labelling; wind energy labels; competitive advantage; premium price; product differentiation

\section{Introduction}

Sustainability is regarded as one of the most complex challenges that businesses must encounter. There is an increasing pressure for companies to broaden its scope through reporting and accountability, moving from economic outcomes for shareholders to sustainability outcomes for all stakeholders [1]. Companies need to finding challenging ways to combat environmental degradation and to increase sustainable performances for all their operational activities.

The literature shows sustainability is multidimensional and incorporates many areas such as sustainable development, human sustainability, social sustainability, ecological sustainability, environmental sustainability, and corporate sustainability [2]. Achieving corporate sustainability involves developing business models for the greening of all their operational activities, in particular, renewable resources and their marketing activities. Against this backdrop, this research looks at how 
sustainability in terms of a business model can use marketing strategies to differentiate products yet, at the same time, deliver value to customers.

Sustainability within businesses is associated to competitiveness, social inclusion, and environmental integrity through the principles of Corporate Social Responsibility (CSR) [3,4]. Business sustainability is characterized as "adopting business strategies and activities that meet the needs of the enterprise and its stakeholders today while protecting, sustaining, and enhancing the human and natural resources that will be needed in the future" [5].

Several authors have devised business models; the Stubbs and Cocklin [2] study demonstrates the "ideal type" of sustainability-oriented business models involving normative principles of organizational development. These authors used case-based theory building for sustainability-oriented business models that involved examples of sustainability-driven organizations such as Interfac Inc. and Bendigo Bank [6]. Apart from other operational and environmental performance measures, their emphasis on the ideal type of sustainability-oriented business models also consisted of structural and cultural attributes of an organization that involves developing community spirit, investing in employees, trust and loyalty, and sustainability assessment and reporting [6].

Teece [7] identifies a fundamental business model as follows:

A business model describes the design or architecture of the value creation, delivery, and capture mechanisms employed. The essence of a business model is that it crystallizes customer needs and ability to pay, defines the manner by which the business enterprise responds to and delivers value to customers, entices customers to pay for value, and converts those payments to profit through the proper design and operation of the various elements of the value chain.

(p. 179)

A green sustainable business model would include objectives that aim towards supporting sustainable development. There is limited literature on how sustainable development is operationalized within firms [8,9]. Sharma [9] is of the opinion that researchers need to theoretically envision structures, strategies, and outcomes as firms move towards obtaining sustainability. There are also suggestions for a more in-depth research to identify business models that can develop competitive solutions for the wellbeing of the natural environment $[6,10]$.

This study reports the findings of a sustainable business model in Nova Scotia (Canada) that demonstrates how renewable energy and wind labeling can extend the competitive advantage of a producer. More specifically, it looks at environmental strategies by integrating marketing strategies to differentiate products yet, at the same time, deliver value to customers. By using qualitative case study techniques, this study generates evidence which suggests how the uses of a product differentiation strategy, premium pricing, and wind labeling strategies can provide associated benefits and value for producers and consumers. First, we apply Porter's generic theory of competitive advantage [11] to show producers can gain a competitive advantage by using wind energy and wind energy labels. Second, we demonstrate that self-declared wind labels can be equally, if not completely, beneficial for producers and retailers, and lastly, we examine the extent to how producers can create consumer confidence in wind labeling which can impact the overall viability of wind energy labeling, thus creating a viable sustainable business model.

The implications of the findings are important for either commercial or agricultural producers, particularly about using wind energy labels. Specifically, there is an apparent paucity with regards to energy labeling and renewable energy. A carefully designed energy labeling strategy aimed at reducing emissions and at the same time differentiating as well as informing consumers of energy use is helpful. The introduction of the new wind energy labeling certification indeed reflects this need. 


\section{Research Method}

There are different reasons where case studies are applied by scientists and researchers, for instance, to test theories [12,13]; to describe [14]; and to advance theory about subjects, themes, or topics [15-17]. These topics can cover various issues that either involve internal organization [18,19], group processes [20], strategy [21], or when one has to extend the knowledge from a specific case to draw inferences about the general case.

Yin [22] suggests that a case study can consist of a single or multiple study for the understanding of the phenomenon. There are several reasons when a single case study method is required. For example, it creates a high-quality theory and a deeper understanding of the subject [23,24]; it also increases the confidence of their representativeness [25]. A case study can capture the intricacies of a single case.

This study applied a single case study research approach [26-28] with a social constructivist perspective [29] to examine the use of wind energy labeling to stimulate consumer demand and to show how producers can benefit from using these labels. A producer is selected as the unit of analysis. A single case is a legitimate qualitative research approach [27,30,31], and in our case, it can contribute to refining theories and to help generate issues for further examination, as well as to help establish some limits to the generalizability [27].

Theory building research is not subordinate to theory testing research [32]. Theory building is achieved by understanding the in-depth view of the single case in particular $[29,33,34]$. A qualitative case study research is relevant for addressing the research questions, partly because of the lack of previous research in wind energy label applications $[29,35]$, and because the research on wind energy labels are largely unexplored, it would be better understood through qualitative research $[26,36]$.

The study examines a producer from an egg production industry in Canada, using a single farm business as the unit of analysis. This single case serves as a revelatory purpose to critically test the existing theory [22]. For this case study, observational research was used that involved a thorough descriptive analysis of the firm to understand and create new findings. It was a naturalistic observation, and the researchers also made use of documents, archives, and other printed material that was available to them.

\section{The Industry}

Prior to the 1950s, the Canadian agricultural industry primarily consisted of small-scale operators. However, as with other industrialized countries, agricultural intensification with an associated intensive input use has helped to consolidate and transform the sector. Farmers' cooperatives, farm inputs companies, and other private firms involved in egg production have helped to transform the activities into a vertically integrated industry, resulting in the industry controlling the outputs produced within the supply chain [37]. Small-scale farming evolved from a secondary to a primary enterprise with specialized farming systems. Since the 1990s, small-scale egg laying hen production emerged partly due to the changing consumer demand for "natural" and organic eggs. Some of the drivers of the growth of the egg industry in Canada include innovation and increased investment by entrepreneurial producers and processors [38].

Canada implements government-supervised poultry, and the egg industry functions under a systematic marketing policy framework called supply management that is proposed to encourage enough volumes of egg production to meet consumer demands [38]. In the province of Nova Scotia, there are several egg graders, packers, and distributors. The industry is regulated by the Provincial Egg Producers organization and with a supply management system to control the supply and demand of eggs [39].

\section{The Business Model}

Bayview Poultry Farm Ltd is a market leader in the industry and one of the very first farms in Nova Scotia, Canada to install wind turbines. The company uses wind energy labels to differentiate its 
product, thereby helping to create a unique product for the consumer market. The eggs produced on Bayview Poultry Farm are promoted to consumers using wind energy labeling on their packaging.

Firms can sustain social and environmental responsibility in several ways, including product stewardship and environmental labels reflecting the use of environmentally friendly production methods. An important objective for a green product is to reflect a producer's responsibility for products at the end of their useful life and, at the same time, reducing the impact on the environment. While this traditional view in theory compels manufacturers and producers to clean up their act, the contemporary view suggests developing product certification and ecolabelling programs [40]. Product certification and environmental labeling programs indicate that the product is environmentally friendly and the manufacturer/producer, at the same time, is also observing their environmental responsibility. Bayview farm implements the provincial environmental farm plan program and practices which help in managing adverse environmental impacts of the farm operation in question.

Producers can use environmental labeling as part of mandatory or regulatory compliance requirements or for anticipated economic benefits. In either case, the adoption of the environmental label may require additional resources and investments. Bayview farm invested in three Skystream 3.7 wind turbines installed on the farm. This produces enough energy on site to keep the farms going [41]. Bayview Farm is a 12,000-laying-hen operation, with 3 Skystream wind turbines which supply about $75 \%$ of the farm's electrical power needs. On-farm electricity cost has been reduced substantially, as well as its output of greenhouse gases [42]. The farm sells some of its eggs to an independent country grocery store within the vicinity, while a larger share of the total production is sold to a distributor under the Maritime Pride label. In addition, the farm's eco-friendly brand is sold to the Sobeys grocery chain [43]. Sobeys Inc. is a large national retail chain in Canada with more than 1300 stores in 10 provinces. Sobeys has other retail operating divisions in the country, including IGA, Foodland, FreshCo, Price Chopper, and Thrifty Foods, which target their products differently to specific consumer segments and niches [44]. Bayview's eco-eggs are also sold to many coop food stores throughout Atlantic Canada.

To help consumers become aware of the eggs produced using green energy from wind turbines, the egg carton packaging comes with the picture of three wind turbines. The egg cartoon package also has the terms "Eco-friendly" and "Produced with Wind Power", along with the company name. Canada requires a standard "Nutrition Facts" label for most prepackaged food products [45]. However, the nutrition label on the Bayview Poultry Farm egg cartoon is inside the cover of the carton. Consumers interested in the nutritional information about the eggs may not readily be aware of this information. In general, the nutrition information is commonly displayed on the outside of the product packaging to help consumers check claims on nutrition. The drawback with their labeling, where there are two or more labels, is that they should be placed on the packaging in a way that minimizes information overload and should be easy for consumers to make an informed choice [46].

The farm has been in operation for over 20 years. It is approximately eight years since the wind turbines were installed, and it appears that consumers continue to buy the eggs, suggesting that the eco-friendly product has met with some success. The market response to Bayview's eco-friendly eggs has been positive, given that various retailers within the chain work closely with Bayview Poultry Farm to promote its environmentally friendly farming methods. A vice president of Coop Atlantic noted that the premium offered for the Bayview Poultry Farms eco-friendly eggs sold in their stores "are the only product on the market that relies on wind power to generate the electricity used in growing these eggs. This provides shoppers with the opportunity to feel good about their purchases. By purchasing Bayview eggs, shoppers are making an impact on the environment, while also supporting our Atlantic First commitment to the region." [47]. By consumers buying eco-friendly eggs, they help- to contribute to value-added environmental activities of the producer. In fact proponents state that sustainable value added shows how much more a company has contributed to sustainability and not necessarily limited to whether a company is sustainable [48]. 


\subsection{Differentiation Strategies}

In this section, we apply a framework underlying Porter's [11] generic theory to explain how the manager of Bayview uses product differentiation strategy and associated benefits to provide value for their consumers. In the early 1990s, the literature shows that low-cost leadership or basic differentiation may not necessarily provide enough of a sustainable competitive edge [49] and that firms are required to do more in terms of sustainability. Integrating environmentalism in marketing enhances a positive corporate image and increases the success of a business enterprise. Corporate environmental responsiveness allows firms to remain competitive, increases market share, and enhances corporate reputation [50-53]. It promotes profitability, improves employee motivation and commitment, and increases customer loyalty [54].

Though there has been a contradiction around the focus of dual competitive strategies, several companies have been successful in using these strategies, i.e., IKEA, Southwest Airlines, Toyota, IBM, Caterpillar, and McDonald's as such examples [55,56]. Similarly, a single strategy has also been very successful with companies such as Walmart and Air Asia [57]. Although Porter's work has been considered in the literature as the most influential and widely tested [58-60], it has also met with several criticisms [61] or suggestions to modify, expand, or combine the strategy topology [62], although lacking specificity for being complex to measure, being superficial, and lacking independence [63]. However, the original model has been recognized and widely used.

An important goal of most entrepreneurs in a market with several economic agents is to achieve a competitive advantage. Porter [11] (1980) noted that two basic strategies that can help attain a competitive advantage relate to competing on production cost or competing by product differentiation. Both strategies offer opportunities to outperform the competition [11]. Market leaders tend to prefer exploiting product differentiation strategies than cost efficiencies, as the former tends to be more profitable over the long-term [58].

Porter [11] views product differentiation in terms of the "uniqueness" in the product offering. Some marketer analysts define differentiation as attributes which are "perceived by the customer to differ from its competition on any physical or nonphysical product characteristic including price" [64] (p. 4). Although product differentiation is particularly relevant for more durable consumer products, Levitt [65] notes that the strategy can also generate successful outcomes for other commodities and can be achieved through branding. Some analysts argue that by endorsing a product label, the product becomes a "self-fulfilling prophecy" [66]. Product differentiation can also be achieved by external means, such as a reputation for reliable delivery or other services offered by the retailer $[67,68]$. The success of this strategy is relevant when there is little that a producer can do to differentiate a product from the competition.

Bayview applies product differentiation by exploiting wind power generated on-farm as a unique attribute in its egg production process. This is a unique first-mover advantage because competitors within the Nova Scotia egg industry had yet to use this green energy system on their farm operations, thereby helping them to position their products on the market. According to Porter [11], uniqueness should have some attributes that are widely valued by buyers [11] and ones that many buyers in a market perceive as important. By differentiating based on green energy, Bayview uses this uniqueness to promote its eggs as "eco-eggs".

\subsection{Premium Price}

According to Porter [11], the uniqueness that producers generate from product differentiation should be rewarded with a premium price to the producer. However, Bayview reported that it does not charge a premium for the eco-eggs it sells to distributors and final retail outlets. Although, there are initial wind turbine installation costs, the manager of Bayview indicated that the wind resource is "free" and can be harnessed to generate electricity. The producer received rebates for the wind power installations under a provincial government green energy program. However, retailers of the eco-eggs, 
such as Sobey's, charge a higher price for the eco-eggs. For example, a dozen eggs in a local Sobeys retail store was sold for $21 \%$ higher than an alternative store brand.

Two important issues related to price premiums emerge from the Bayview case study, namely, (i) consumer willingness to pay premium prices and (ii) vertical integration in the egg distribution chain and the consequences for charging premium prices.

On eco-products, there is a controversy over premium prices. For instance, the Food and Water Europe [69], a consumer advocacy organization, noted that eco-labels can help increase the public acceptance of products produced using controversial farming operations. On the other hand, some consumers are willing to pay a premium for green products endorsed with environmental labels [70-74], while others are willing to pay higher prices but unwilling to compromise on product quality regardless [75].

In a survey of 25,000 internet respondents in 51 countries, Nielson [76] reported that $22 \%$ of respondents would pay more for "eco-friendly" products [76]. Some consumers are willing to pay even up to the extent of $10 \%$ more for socially responsible products [77]; on the other hand, the Boston Consulting Group in 2008 surveyed 9000 consumers in 9 countries, Canada being one of them, and found that about $30 \%$ of consumers are willing to pay a $10 \%$ premium on ingestibles such as meat, dairy, seafood, and other produce [78]. Nonetheless, the National survey sponsored by Dupont and Mohawk Industries interviewed 1001 US homeowners and found that consumers would pay at least $5 \%$ more for products made with renewable resources [79]. In summary, some consumers are willing to pay a premium for green products. For commodities like eggs, as suggested above, it is more likely to demand a premium of $10 \%$; however, the "eco-friendly" eggs produced by Bayview was retailing for $21 \%$ more than other store brands.

According to Porter's [11] notion of product differentiation, product uniqueness is inherently costly. Thus, it is important to have price premiums to cover the cost associated with such uniqueness (if any). On other hand, other analysts suggest that a differentiation strategy can help lower cost by increasing sales volume, efficiencies in the learning curve, and economies of scale and scope [80,81]. By using wind energy on the farm, Bayview reported to the Nova Scotia Federation of Agriculture that the on-farm wind energy produced significantly reduced its electricity costs and greenhouse gas emissions [41]. Porter [11] argues that differentiation is "usually" costly to a firm, but this is a unique case, as for Bayview that uses wind energy, the cost to produce is cheaper. The gains in cost efficiencies may accrue directly to the producer or passed on to retailers in a supply chain that is vertically integrated.

\subsection{Bayview's Wind Labeling Strategy}

The intention behind labelling is that consumers should be able to use them in their decision making [82]. Three arguments arise from Bayview's wind label influences; one is how is information about the label presented to the consumer and the ability of the consumer to engage [83]? Secondly, how will consumers act on wind labels [84]? Third, how does the consumer trust the label to help them to attain some goal [85]?

\subsubsection{Consumer Information}

The conduit for evaluating environmental labels is not the producer but the consumer to make an informed choice. The primary question, however, is does wind labelling have the power to influence consumer choice as it has so intended? The goal of consumer policy for environmental labelling is to enable consumers to make an informed choice through education and information [85], for the information to be timely, and for claims to be relevant [83]. The claims made on the label by Bayview are accurate as it indicates the eggs produced uses wind energy. In general, this is an important criterion for labelling.

The literature identifies that unlike other labelling processes where consumers strongly demand appropriate label information, there appears to be considerable uncertainty on labelling 
information [86-88]. Labelling should be clear, allowing the consumer to avoid misrepresentation about environmental attributes; it must be transparent, truthful, discriminatory, based on sound science, and substantiated and must not mislead consumers [89-92]. In Bayview's case, the label is easy to read and understand but limited in its form; as such, it only states "Eco-friendly" and "Produced with Wind Power".

What consumers know and how they understand is important to our understanding of wind label adoption. This is best described by the theory of information economics which shows how information affects an economy and economic decisions; it gives a more realistic view of a market exchange between a buyer and seller [93]. In comparison to other forms of labeling, one may argue that Bayview Poultry only demonstrates a symbol of the windmill, with eco-friendly written on the packaging; it stands to argue whether this information is enough for consumers to make an informed choice.

This can be explained by how consumers seek information. Karstens and Belz [93] explain using the work of Nelson [94,95] and of Darby and Karni [96] who suggest that when buying products for the first time, consumers only have a limited means of information about the price and quality of the product, the consumer needs to search for more information. Here, search means that the product quality can be inspected by the consumer prior to purchase; if the quality cannot be inspected by the consumer prior to purchase, then consumers buy the product and experience the quality by using it. Extending Nelson's work, Darby and Karni [96] introduced a third quality, called credence qualities, whereby product qualities cannot be evaluated by a search prior to purchase or by experience after purchase. Hence, other attributes of the product such as eco-friendliness can take predominance; this is precisely in the case of Bayview's wind energy labels.

\subsubsection{Consumer Actions}

Consumer actions largely depend on behavior, and whether a person will undertake to accept wind labelling specifically simply does not stand up to drawing a general examination; instead, there could be other factors that require examination, such as their opinions towards wind technology, consumer psychographics, personality, and other behavioural determinants. Straughan and Roberts [97] clearly identified that concerns about the environment can have a poor effect, but the extent to which the individual consumer believes that his or her actions are likely to make a difference will have a significant effect on the environment. This is called perceived consumer effectiveness. Perceived consumer effectiveness has been found to have a positive effect on attitudes and environmentally conscious behaviour relationship $[98,99]$.

Like with any technology, there are mixed opinions, and the same coexists with wind energy. While there are some survey reports that support this technology [100,101], many have disagreed with wind energy. For instance, the social acceptance of wind technology is also seen as problematic [102]. There is a strong local opposition with renewal energy [103-106]. These are important considerations in terms of wind technology that will influence consumers to act in favour of wind labeling.

In effect, researchers have that identified wind farms create an impression on aesthetic stigmas, which has evoked emotions within the community [107]. These emotions can be unsupported if they are negative and can be more damaging, as Coddington [108] has pointed out that green consumption also implies the satisfaction of consumer's emotional needs. In response to this and other manifestations, notably, emotional benefits such as intrinsic value felt by consumers when supporting a deserving cause, often driven by this "warm glow of giving", can be derived from the product $[109,110]$. Similarly, Ritov and Kahnemann [111] expressed that those consumers had a feeling of wellbeing ("warm glow") and also associated with acting in an altruistic way [112]. In the case of Bayview labels, it has a symbolic representation of wind mills, which creates a semiotic emotional meaning of wind energy. Further research is required to probe into determining the type of emotional impacts that drive decisions.

Wind labels in Bayview's case displayed energy usage; other attributes of the product are also beneficial to the consumer. Consumers attempt to buy products based on the inherent functional values of a product. In other words, the functional aspect should be seen as beneficial to the consumer. 
The functional value of the eggs can range from being organic, vegetarian, omega- 3 enhanced, vitamin enhanced, or free range and free run. Orth and De Marchi [113] suggest that the functional benefits are largely associated to the inherent advantages of the consumption status of the product and correspond to attributes of the product that motivates consumers. How consumers act will largely depend on the nature of the consumer and their needs hierarchy; for instance, those with altruistic obligation about the environment will be more inclined to use wind labels for making purchases. Instead, not all consumers will readily accept wind label; there will only be a particular niche market or segment of a market that are willing to buy wind-labelled products or green products.

\subsubsection{Consumer Trust}

Bayview's labeling is categorized as type II labeling, that is self-declared labels, which are normally endorsed by the producer. Typically, type I labels are voluntary and uses multiple measures to access environmental programs by manufactures. Companies meeting their standards are awarded the label. This labeling is endorsed by independent third parties. Type III, on the other hand, uses a higher quantitative-based assessment to assess product life cycle data; this is also endorsed by third parties [114]. Do type II labels used by self-producers put Bayview to a disadvantage? Type II labels are likely to distort Bayview's credibility of the label, as it is endorsed by the producers themselves and unlike type I or III labels which are endorsed by credible third-party sources. Furthermore, consumers require a level of trust and knowledge on the endorsement of the wind label. Since this is a self-regulated label endorsed by the producer, consumers would have to trust the producer.

Trust, in terms of wind labelling, can be seen as "having faith or trust in the efficacy of authorities" $[115,116]$. Wind labels, in particular the new type III labels as compared to the self-regulated labels, have credentials as they are endorsed by third party, owing to how much confidence consumers have in the third-party accreditation. On the other hand, self-regulated labels used by Bayview works based on Bagozzi and Dabholkar [117] who suggest an analysis of the means-end chain where egoistic and altruistic goals persuade environmental behaviour, but if altruistic goals have a greater tendency to motivate, then even self-declared labels will appeal to this sort of behaviour.

\section{Wind Energy Labelling}

The idea of environmental labeling is widely accepted because it advocates marketing promotion and has long been known to be a support mechanism towards consumer application for green choices. Universally, these environmental labels can be affirmed directly by symbols, emblems, logos, or words. While they can be implicitly or explicitly expressed, these labels are only practical if they fulfill their intended goals [82]. No doubt, from a marketing perspective, environmental labels can assist producers to expand their market share and become competitive [118] and, if designed carefully, have a tendency to improve sales and to assist firms to improve all around environmental performance [82].

Wind energy is a clean source of renewable energy, and its new official label is making an entry in the market for entrepreneurs, producers, both suppliers (manufacturers/importers), and retailers. Wind labeling provides an opportunity to more widely publicize the benefits connected with using energy from renewable technologies [119]. The wind energy consortium (consisting of the Global Wind Energy Council, World Wildlife Fund (WWF), the LEGO Group, and UN Global Compact) started an initiative to develop the first global consumer label that identifies a product made using wind power. The consortium is expanding to include over 6200 organizations in over 130 countries [120]. This proposal for the first global consumer label for wind energy labelling started in January 2011, with the WindMade ${ }^{\mathrm{TM}}$ consolidating its proposal in June 2011. The standard stipulates that participating member companies have to source a minimum of $25 \%$ of their electricity from wind power. The advent of this formal wind label is categorized as a type III environmental label. Although, the traditional benefits of wind energy are known, a better understanding of wind energy labeling is required to examine how they are likely to influence market behavior at two levels: the adoptive behavior of 
consumers at the consumer level and at the firm level, the benefits that firms would yield at an optimal outcome if they use wind labels.

Different stakeholders' benefit from wind energy labeling. From a consumer's perspective, environmental labels allow consumers to make an informed environmental choice. From a producer's perspective, it aims to assist producers to become more socially responsible and is able to differentiate their products, thereby gaining a competitive advantage. Labelling is often viewed by producers as a cooperative association between government regulators and businesses. From a government's perspective, governments have responded by sorting, implementing, and validating eco-labeling programs that involve over thousands of products in varying countries [121] and that are often introduced as a suitable, though partial, policy tool to regulate environmental problems [122]. The social acceptance of wind energy was also found to be positive [123].

\section{Managerial Implications}

However, further research is required to identify the feasibility of wind energy labelling and its performance which remains to be questioned. Some assumptions based on the case can be made in terms of managerial implications. Wind energy and wind energy labelling is effective on two levels: the firm level and the consumer level. On the firm front, it can be seen that wind energy and labelling influences competitive advantage of firms, dictates a premium price, and can differentiate products, yet achieve a low-cost advantage. Wind labels also have the potential to drive the supply chain's environmental value to the consumer as end user, by requiring the distribution chain to follow good environmental practices. The producer can create a domino effect.

On the consumer level, by the evidence and success of Bayview using self-declared wind labels, we make the observation that wind labels further question many issues in terms of consumers using wind labels for differentiation. Furthermore, a well-designed environmental label needs to motivate consumers to adapt to environmental practices. In terms of label information, whereby product qualities cannot be evaluated by a search prior to purchase or by experience after purchase, eco-friendliness of the product can take predominance, which is the apparent case for Bayview. Not all consumers will buy eco-friendly eggs; instead, there could be other factors that drive consumers such as their opinions towards wind technology, consumer psychographics, personality, and other behavioural determinants. Hence, Bayview's case is a case of a strong niche market. Finally, for the trust in labels, however, Bayview does not have third party accreditation, yet the labels seem to work for them; this could purely be contributed to a means-end chain analysis, where egoistic and altruistic goals compel environmental behaviour.

The generalizations of a single case study cannot be made, but some recommendations can be provided in terms of managerial implications. Managers can take a proactive view on using wind energy to build a strong competitive advantage for their products, which, in turn, would also help in operationalizing environmentally clean technologies within their sustainable business model. This will lead to developing a positive and ethical corporate image. In terms of customer interventions by introducing green operations, the sustainable business model is likely to meet customers' expectations, to improve market share, and potentially to achieve a long-term profit for this niche market. Ecolabelling with third party accreditation can be obtained to allow consumers to make an informed choice.

\section{Limitations and Future Research}

The main limitation of the study is that it is a single case study, whereby robust generalizations cannot be inferred; thus, examining a larger qualitative sample is required, whereby the depth and intricacy of the case study data can demonstrate how such correlated factors influence each other. Future research can quantify the methodology to provide further insights into sustainable business models. Expanding consumer insights to further describe the relationship of buying behaviour and consumer characteristics may provide a useful understanding for green niche markets and how they 
can be translated in buying action. Other operational aspects can be considered, apart from marketing strategies and renewable resources.

\section{Conclusions}

The sustainable business model demonstrates that producers and retailers that use wind energy to differentiate their produce can obtain a competitive advantage. This case scenario as an analogy is a compelling argument on how investing in wind energy labels can increase consumer confidence despite the odds on the literature suggesting otherwise. Presenting the concept of wind energy, as a means of confronting producers and manufacturers challenges an ambitious undertaking, in which green products and environmental labels logically play an important role. Contrary to popular belief, wind energy labels can create a huge impact on consumers' decision making. The unintended causes of wind energy and contemporary challenges are outlined and discussed along with appropriate assumptions. For the new wind energy labeling being introduced in the form of type III, this research forms a platform as a compelling starting point for future research.

In conclusion, these types of consumers that will be receptive towards wind technology are also consumers with pro-environmental characteristics. These niche segments of consumers are those that will associate with environmental labels and pursue those labels to make choices. The trust in the labels is also critical and so is the functional value of the product that should also be considered. Producers should be aware of the emotional impact the environment can have on certain consumers. In principle, there appears to be an opportunity for wind labelling to be successful in practice; it is bound to attract a particular niche market.

Author Contributions: Conceptualization, C.D. and E.K.Y.; methodology, C.D. and E.K.Y.; formal analysis, C.D. and E.K.Y.; investigation, C.D. and E.K.Y.; writing-original draft preparation, C.D. and E.K.Y.; writing一review and editing, C.D. and E.K.Y.; project administration, C.D. and E.K.Y.

Funding: This research received no external funding.

Conflicts of Interest: The authors declare no conflict of interest.

\section{References}

1. Visser, W.T. Sustainability reporting in South Africa. Corp. Environ. Strategy 2002, 9, 79-85.

2. Stubbs, W.; Cocklin, C. Conceptualizing a "sustainability business model". Organ. Environ. 2008, 21, $103-127$. [CrossRef]

3. Huber, P.; Nerudová, D.; Rozmahel, P. Competitiveness, Social Inclusion and Sustainability in a Diverse European Union; Springer: Berlin, Germany, 2015.

4. Kopnina, H. Sustainability: New strategic thinking for business. Environ. Dev. Sustain. 2017, 19, $27-43$. [CrossRef]

5. Deloitte \& Touche ISSD. Business Strategy for Sustainable Development: Leadership and Accountability for the 90s; IISD: Winnipeg, MB, Canada, 1992.

6. Schaltegger, S.; Hansen, E.G.; Lüdeke-Freund, F. Business models for sustainability: Origins, present research, and future avenues. Organ. Environ. 2016, 29, 3-10. [CrossRef]

7. Teece, D. Business models, business strategy and innovation. Long Range Plan. 2010, 43, 172-194. [CrossRef]

8. Bansal, P.; Roth, K. Why companies go green: A model of ecological responsiveness. Acad. Manag. J. 2000, 43, 717-736.

9. Sharma, S. Research in corporate sustainability: What really matters? In Research in Corporate Sustainability: The Evolving Theory and Practice of Organizations in the Natural Environment; Sharma, S., Starik, M., Eds.; Edward Elgar: Cheltenham, UK, 2002; pp. 1-29.

10. Boons, F.A.A.; Lüdeke-Freund, F. Business models for sustainable innovation: State-of-the-art and steps towards a research agenda. J. Clean. Prod. 2013, 45, 9-19. [CrossRef]

11. Porter, M.E. Competitive Strategy; Free Press: New York, NY, USA, 1980.

12. Anderson, P.A. Decision making by objection and the cuban missile crisis. Adm. Sci. Q. 1983, 28, $201-222$. [CrossRef] 
13. Pinfield, L.T. A field evaluation of perspectives on organizational decision making. Adm. Sci. Q. 1986, 31, 365-388. [CrossRef]

14. Kidder, T. Soul of a New Machine; Avon: New York, NY, USA, 1982.

15. Harris, S.G.; Sutton, R.I. Functions of parting ceremonies in dying organizations. Acad. Manag. J. 1986, 29, 5-30.

16. Gersick, C.J.G. Time and transition in work teams: Toward a new model of group development. Acad. Manag. J. 1988, 31, 9-41.

17. Mintzberg, H. An emerging strategy of "direct" research. Adm. Sci. Q. 1979, 24, 582-589. [CrossRef]

18. Gilbert, C.G. Unbundling the structure of inertia: Resource versus routine rigidity. Acad. Manag. J. 2005, 48, 741-763. [CrossRef]

19. Galunic, D.C.; Eisenhardt, K.M. Architectural innovation and modular corporate forms. Acad. Manag. J. 2001, 44, 1229-1249.

20. Edmondson, A.C.; Bohmer, R.M.; Pisano, G.P. Disrupted routines: Team learning and new technology implementation in hospitals. Adm. Sci. Q. 2001, 46, 685-716. [CrossRef]

21. Mintzberg, H.; Waters, J.A. Tracking strategy in an entrepreneurial firm. Acad. Manag. J. 1982, $25,465$.

22. Yin, R. Case Study Research: Design and Methods, 1st ed.; Sage Publishing: Beverly Hills, CA, USA, 1984.

23. Gustafsson, J. Single Case Studies vs. Multiple Case Studies: A Comparative Study. 2017. Available online: Divaportal.org (accessed on 24 February 2019).

24. Dyer, W.G., Jr.; Wilkins, A.L.; Eisenhardt, K.M. Better stories, not better constructs, to generate better theory: A rejoinder to Eisenhardt; better stories and better constructs: The case for rigor and comparative logic. Acad. Manag. Rev. 1991, 16, 613. [CrossRef]

25. Gerring, J. What Is a Case Study and What Is It Good for? Am. Political Sci. Rev. 2004, 98, 341-354. [CrossRef]

26. Baxter, P.; Jack, S. Qualitative case study methodology: Study design and implementation for novice researchers. Qual. Rep. 2008, 13, 544-559.

27. Stake, R.E. Case studies. In Handbook of Qualitative Research; Denzin, N.K., Lincoln, Y.S., Eds.; Sage Publications: Thousand Oaks, CA, USA, 1994.

28. Eisenhardt, K.M. Building theories from case study research. Acad. Manag. Rev. 1989, 14, 532-550. [CrossRef]

29. Teddlie, C.; Tashakkori, A. Foundations of Mixed Methods Research: Integrating Quantitative and Qualitative Approaches in the Social and Behavioral Sciences; Sage Publications: Thousand Oaks, CA, USA, 2009.

30. Creswell, J. Research Design: Qualitative, Quantitative and Mixed Methods Approaches, 2nd ed.; Sage Publications: Thousand Oaks, CA, USA, 2003.

31. Denzin, N.K.; Lincoln, Y.S. Introduction: The discipline and practice of qualitative research. In Handbook of Qualitative Research, 2nd ed.; Denzin, N.K., Lincoln, Y.S., Eds.; Sage Publications: Thousand Oaks, CA, USA, 2000; pp. 1-28.

32. Andrade, A.D. Interpretive research aiming at theory building: Adopting and adapting the case study design. Qual. Rep. 2009, 14, 42-60.

33. Creswell, J. Research Design: Qualitative, Quantitative and Mixed Methods Approaches, 3rd ed.; Sage Publications: Thousand Oaks, CA, USA, 2009.

34. Gall, M.; Borg, W.; Gall, J. Educational Research: An Introduction; Longman: White Plains, NY, USA, 1996.

35. Strauss, A.; Corbin, J. Basics of Qualitative Research: Techniques and Procedures for Developing Grounded Theory; Sage Publications: Thousand Oaks, CA, USA, 1998.

36. Rossman, G.; Rallis, S. Learning in the Field: An introduction to Qualitative Research, 2nd ed.; Sage Publications: Thousand Oaks, CA, USA, 2003.

37. Meunier, R.; Latour, M. Commercial Egg Production and Processing. 2004. Available online: http:/ /ag.ansc. purdue.edu/poultry/publication/commegg/ (accessed on 27 September 2011).

38. Agriculture and Agri-Food Canada (AAC). Snapshot of the Canadian Egg Industry. 1999. Available online: http:/ / dsp-psd.pwgsc.gc.ca/Collection/A84-1-1999E.pdf (accessed on 27 September 2011).

39. Nova Scotia Egg Producers. About Nova Scotia Egg Producers. 2007. Available online: http://www.nsegg. ca/about.htm (accessed on 27 September 2011).

40. Stewardship Ontario. Thinking Beyond the Box. 2011. Available online: http://www.stewardshipontario. $\mathrm{ca} /$ product-stewardship?path\%5Bnid $\% 5 \mathrm{D}=1$ (accessed on 27 September 2011).

41. Nova Scotia Federation of Agriculture. Green Eggs from Masstown. 2008. Available online: http://www. nsfa-fane.ca/Green_Eggs_from_Masstown (accessed on 27 September 2011). 
42. Woolley, D. On Farm Win Power-Bay View Poultry Farms Installs Wind Turbines, Canadian Poultry. 2007. Available online: http:/ / www.canadianpoultrymag.com/content/view/1059/132/ (accessed on 27 September 2011).

43. Harrington, L. Grading Operation Becomes Egg-tinct. Shorel. J. 2011. Available online: http://www. theshorelinejournal.com/apr1116.pdf (accessed on 25 February 2019).

44. Sobeys. Sobeys Corporation. 2011. Available online: http://www.sobeyscorporate.com/en/Home.aspx (accessed on 7 February 2019).

45. Health Canada. Food and Nutrition. 2010. Available online: http://www.hc-sc.gc.ca/fn-an/label-etiquet/ nutrition/index-eng.php (accessed on 27 September 2011).

46. Horne, R.; Wasiluk, K.; Gertsakis, J. Rapid life cycle assessment design tools and theirh role in DFE transitions in Australia. In Proceedings of the 5th International Conference on Design and Manufacture for Sustainable Development, Sustain 07, Loughborough, UK, 10-11 July 2007.

47. Coop Atlantic. Want Green Eggs with That ham? New Eco-Friendly Product Blows onto Shelves of Co-Op Stores. 2008. Available online: http:/ / www.coopatlantic.ca/htm.aspx?id=602 (accessed on 27 September 2011).

48. Figge, F.; Hahn, T. Sustainable value added-measuring corporate contributions to sustainability beyond eco-efficiency. Ecol. Econ. 2004, 48, 173-187. [CrossRef]

49. Reed, P. Strategic Marketing Planning; Nelson Australia Pty. Ltd Trading as Thomson Learning Australia: Victoria, Australia, 2003.

50. Menon, A.; Menon, A. Enviropreneurial marketing strategy: The emergence of corporate environmentalism as market strategy. J. Mark. 1997, 61, 51-67. [CrossRef]

51. Shrivastava, P. Environmental technologies and competitive advantage. Strateg. Manag. J. 1995, 16, $183-200$. [CrossRef]

52. Chan, R.Y. Determinants of Chinese Consumers-Green Purchase Behaviour. Psychol. Mark. 2001, 18, 389-413. [CrossRef]

53. Porter, M.; Van der Linde, C. Green and Competitive: Ending the stalemate. Harv. Bus. Rev. 1995, 73, 120-134.

54. Forte, M.; Lamont, B. The bottom-line effect of greening (implications of ecological awareness). Acad. Manag. Exec. 1998, 12, 89-91.

55. Minarik, M. Cost Leadership \& Differentiation-An Investigation of the Fundamental Trade-Off between Porter's Cost Leadership and Differentiation Strategies. Master's Thesis, Stockholm School of Economics, Institute of International Business, Stockholm, Sweden, 2007. Available online: http:/ /arc.hhs.se/download. aspx?MediumId=315 (accessed on 25 February 2019).

56. Acquaah, M.; Yasai-Ardekani, M. Does the implementation of a combination competitive strategy yield incremental performance benefits? A new perspective from a transition economy in Sub-Saharan Africa. J. Bus. Res. 2008, 61, 346-354. [CrossRef]

57. Baroto, M.B.; Abdullah MM, B.; Wan, H.L. Hybrid strategy: A new strategy for competitive advantage. Int. J. Bus. Manag. 2012, 7, 120.

58. Hambrick, D.C. High profit strategies in mature capital goods industries: A contingency approach. Acad. Manag. J. 1983, 26, 687-707.

59. Dess, G.G.; Davis, P.S. Porter's generic strategies as determinants of strategic group membership and organizational performance. Acad. Manag. J. 1984, 27, 467-488.

60. Akan, O.; Allen, R.S.; Helms, M.M.; Spralls, S.A., III. Critical tactics for implementing Porter's generic strategies. J. Bus. Strategy 2006, 27, 43-53. [CrossRef]

61. Speed, R.J. Oh Mr Porter! A re-appraisal of competitive strategy. Mark. Intell. Plan. 1989, 7, 8-11. [CrossRef]

62. Miles, R.; Snow, C. Organizational Strategy, Structure, and Process; McGraw-Hill Book Company: New York, NY, USA, 1978.

63. Martin, R.; Sunley, P. Deconstructing clusters: Chaotic concept or policy panacea? J. Econ. Geogr. 2003, 3, 5-35. [CrossRef]

64. Dickson, P.R.; Ginter, J.L. Market segmentation, product differentiation, and marketing strategy. J. Mark. 1987, 51, 1-10. [CrossRef]

65. Levitt, T. Marketing success through the differentiation-of anything. Harv. Bus. Rev. 1980, 58, 83-91. 
66. Peters, T.; Austin, N. A Passion for Excellence: The Leadership Difference; Random House: New York, NY, USA, 1985; In Datta, Y. A critique of Porter's cost leadership and differentiation strategies. In Proceedings of the 9th Oxford Business \& Economics Conference, Oxford, UK, 22-24 June 2009.

67. Caves, R.E. American Industry: Structure, Conduct, Performance, 6th ed.; Prentice Hall: Englewood, NJ, USA, 1987.

68. Lawless, M.W. Commodity bundling for competitive advantage: Strategic implications. J. Manag. Stud. 1991, 28, 267-280. [CrossRef]

69. Food and Water Europe. De-Coding Seafood Eco-Labels: How the European Commission Can Help Consumers Access Sustainable Seafood. 2010. Available online: http://www.foodandwaterwatch.org/ reports/de-coding-seafood-eco-labels-europe/ (accessed on 11 October 2011).

70. Gumpper, M. Do consumers respond to eco-labels: Evidence from a market 21 experiment using contingent valuation. Pa. Econ. Rev. 2000, 9, 14-22.

71. Imkamp, H. The interest of consumers in ecological product information is growing-evidence from two German surveys. J. Consum. Policy 2000, 23, 193-202. [CrossRef]

72. Loureiro, M.; McCluskey, J.; Mittelhammer, R. Will consumers pay a premium for eco-labeled apples? J. Consum. Aff. 2002, 36, 203-219. [CrossRef]

73. Makatouni, A. What motivates consumers to buy organic food in the UK? Br. Food J. 2002, 104, $345-352$. [CrossRef]

74. Moon, W.; Florkowski, W.; Bruckner, B.; Schonhof, I. Willingness to pay for environmental practices: Implications for eco-labeling. Land Econ. 2002, 78, 88-102. [CrossRef]

75. D'Souza, C.; Taghian, M.; Lamb, P.; Peretiatko, R. Green decisions: Demographics and consumer understanding of environmental labels. Int. J. Consum. Stud. 2007, 31, 371-376. [CrossRef]

76. Neilsen Survey Reports. Global Online Environment \& Sustainability Survey. 2011. Available online: http:/ / www.bizreport.com/2011/09/nielsen-20-of-consumers-will-pay-more-for-eco-friendlyprodu.html (accessed on 27 September 2011).

77. Springen, K.; Miller, A. Doing the right things. Newsweek 1991, 117, $23-42$.

78. Manget, J.; Roiche, C.; Munnich, F. Boston Consulting Group Report: Capturing the Green Advantage for Consumer Companies; Boston Consulting Group MA: Boston, MA, USA, 2009.

79. Wilmington News. Survey: Consumers willing to pay more for green products. Wilmington News J. 14 April 2008.

80. Hill, C.W. Differentiation versus low cost or differentiation and low cost: A contingency approach. Acad. Manag. Rev. 1988, 13, 401-412. [CrossRef]

81. Pitelis, C.; Taylor, S. From generic strategies to value for money in hypercompetitive environments. J. Gen. Manag. 1996, 21, 45-61. [CrossRef]

82. OECD. Eco-Labelling: Actual Effects of Selected Programs; Head of Publication Service: Paris, France, 1997; $\mathrm{V}($ No.44).

83. Scammon, J.R.; Mayer, R.N. Environmental labeling and advertising claims: International action and policy issues. Eur. Adv. Consum. Res. 1993, 1, 338-344.

84. Teisl, M.; Rubin, J.; Noblet, C. Non dirty dancing? Interaction between eco-labels and consumers. J. Econ. Psychol. 2008, 29, 140-159. [CrossRef]

85. Thogersen, J. Psychological determinants of paying attention to eco-labels in purchse decisions: Model development and multinational validation. J. Consum. Policy 2000, 23, 285-313. [CrossRef]

86. Caswell, J.; Mojduszka, E. Using Informational Labelling to Influence the Market for Quality in Food Products; Food Marketing Policy Center, University of Connecticut: Storrs Mansfield, CT, USA, 1996.

87. Muller, T.E. Structural Information Factors, which Stimulate the use of Nutrition Information: A Field Experiment. J. Mark. Res. 1985, 22, 68-75. [CrossRef]

88. Robertson, K.M.; Marshall, R. Amount of label information effects on perceived product quality. Int. J. Advert. 1987, 6, 199-205. [CrossRef]

89. Carlson, L.; Grove, S.; Kangun, N. A Content Analysis of Environmental Advertising Claims: A Matrix Method Approach. J. Advert. 1993, 22, 27-40. [CrossRef]

90. Davis, J.J. Consumer Response to Corporate Environmental Advertising. J. Consum. Mark. 1994, 11, $25-37$. [CrossRef]

91. Petty, R.D.; Gray-Lee, J.W.; Scammon, D.L.; Mayer, R.N. Review of Legal Standards for Environmental Marketing Claims. J. Public Policy Mark. 1994, 13, 155-159. [CrossRef] 
92. Polonsky, M.J.; Bailey, J.; Baker, H.; Basche, C.; Jepson, C.; Neath, L. Communicating Environmental Information: Are Marketing Claims on Packaging Misleading? J. Bus. Ethics 1998, 17, 281-294. [CrossRef]

93. Karstens, B.; Belz, F. Information asymmetries, labels and trust in the German food market: A critical analysis based on the economics of information. Int. J. Advert. 2006, 25, 281-294. [CrossRef]

94. Nelson, P. Information and consumer behavior. J. Political Econ. 1970, 78, 311-329. [CrossRef]

95. Nelson, P. Advertising as information. J. Political Econ. 1974, 82, 729-854. [CrossRef]

96. Darby, M.; Karni, E. Free competition and the optimal amount of fraud. J. Law Econ. 1973, 16, 67-68. [CrossRef]

97. Straughan, R.; Roberts, J. Environmental segmentation alternatives: A look at green consumer behavior in the new millennium. J. Consum. Mark. 1999, 16, 558-569. [CrossRef]

98. Berger, I.E.; Corbin, R.M. Perceived consumer effectiveness and faith-in-others as moderators of environmentally responsible behaviors. J. Public Policy Mark. 1992, 11, 79-89. [CrossRef]

99. Ellen, P.S.; Weiner, J.L.; Cobb-Walgren, C. The role of perceived consumer effectiveness in motivating environmentally conscious behaviors. J. Public Policy Mark. 1991, 10, 102-117. [CrossRef]

100. Wüstenhagen, R.; Wolsink, M.; Bürer, M.J. Social acceptance of renewable energy innovation: An introduction to the concept. Energy Policy 2007, 35, 2683-2691. [CrossRef]

101. Carlman, I. Wind energy potential in Sweden: The importance of non-technical factors. In Proceedings of the Fourth International Symposium on Wind Energy Systems, Stockholm, Sweden, 21-24 September 1982; pp. 335-348.

102. Wolsink, M. Wind power for the electricity supply of houses. Neth. J. Hous. Environ. Res. 1987, 2, $195-214$. [CrossRef]

103. Toke, D. Explaining wind power planning outcomes: Some findings from a study in England and Wales. Energy Policy 2005, 33, 1527-1539. [CrossRef]

104. Upham, P.; Shackley, S. Stakeholder opinion of a proposed 21.5 M We biomass gasifier in Winkleigh, Devon: Implications for bioenergy planning and policy. J. Environ. Policy Plan. 2006, 8, 45-66. [CrossRef]

105. Warren, C.R.; Lumsden, C.; O'Dowd, S.; Birnie, R.V. Green on Green': Public Perceptions Wind Power in Scotland and Ireland'. J. Environ. Plan. Manag. 2005, 48, 853-875. [CrossRef]

106. Horbaty, R.; Huber, S. Social acceptance of wind energy projects: IEA wind Task 28, Winning hearts and minds. In Proceedings of the EWEC, Warsaw, Poland, 20-23 April 2010.

107. Ingham, B.; Gipe, P. Wind Energy Comes of Age; John Wiley \& Sons: New York, NY, USA, 1995.

108. Coddington, W. Environmental Marketing: Positive Strategies for Reaching the Green Consumer; McGrawHill: New York, NY, USA, 1993.

109. Menges, R. Supporting renewable energy on liberalized markets: Green electricity between additionality and consumer sovereignty. Energy Policy 2003, 31, 583-596. [CrossRef]

110. Boyce, R.; Brown, T.C.; McClelland, G.H.; Peterson, G.L.; Schulze, W.D. An experimental examination of intrinsic values as a source of the WTA-WTP disparity. Am. Econ. Rev. 1992, 82, 1366-1373.

111. Ritov, I.; Kahneman, D. How people value the environment: Attitudes versus economic values. In Psychological Perspectives to Environmental and Ethical Issues; Bazerman, M., Messick, D., Tenbrunsel, A., Wade-Benzoni, K., Eds.; The New Lexington Press: San Francisco, CA, USA, 1997; pp. 33-51.

112. Hartmann, P.; Ibanez, V.A.; Sainz, F.J. Green branding effects on attitude: Functional versus emotional positioning strategies: Functional versus emotional positioning Strategies. Mark. Intell. Plan. 2005, 23, 9-29. [CrossRef]

113. Orth, U.R.; De Marchi, R. Understanding the Relations between Functional, Symbolic, and Experiential Brand Beliefs, Product Experiential Attributes, and Product Schema: Advertising-Trial Interactions Revisited. J. Mark. Theory Pract. 2007, 15, 219-233. [CrossRef]

114. UNEP. Environment and Trade: A Handbook, Published by IISD. 2000. Available online: http:/ / www.iisd. org/trade/handbook/5_4_1.htm (accessed on 27 October 2012).

115. Hassan, S.; Vandermerwe, S. A Global View of "Green marketing" in Global Marketing Perspectives and Cases; Hassan, S., Blackwell, R., Eds.; The Dryden Press-Harcourt Brace \& Co.: San Diego, CA, USA, 1994; pp. 101-118.

116. Muska, A. The Challenge of Independent Corporate Environmental Performance Evaluation. In Environmental Management and Business Strategy; Piasecki, B., Fletcher, K., Mendelson, F., Eds.; John Wiley and Sons: Hoboken, NJ, USA, 1998; pp. 323-325. 
117. Bagozzi, R.P.; Dabholkar, P.A. Consumer recycling goals and their effect on decisions to recycle: A means-end chain analysis. Psychol. Mark. 1994, 11, 313-340. [CrossRef]

118. Hickle, G. Promoting product stewardship with eco-labels, certification programs, and product standards. Environ. Qual. Manag. 2007, 16, 1-9. [CrossRef]

119. Harrington, L.; Damnics, M. Energy Labeling and Standards programs Throughout the World; Edition 2.0; The National Appliance and Equipment Energy Efficiency Committee: Melbourne, Australia, July 2004.

120. Gunshinan, J. A New Energy Label Promotes Wind Power. Available online: http://science.kqed.org/quest/ 2011/02/11/new-label-wind-energy/ (accessed on 30 August 2011).

121. US Report U.S. Environmental Protection Agency. Status Report on the Use of Environmental Labels Worldwide; US Environmental Protection Agency: Washington, DC, USA, 1993.

122. Mattoo, A.; Singh, H. Eco-Labelling: Policy Considerations. Kyklos 1994, 47, 53-65. [CrossRef]

123. D'Souza, C.M.; Yiridoe, E.K. Social acceptance of wind energy development and planning in rural communities of Australia: A consumer analysis. Energy Policy 2014, 74, 262-270. [CrossRef]

(C) 2019 by the authors. Licensee MDPI, Basel, Switzerland. This article is an open access article distributed under the terms and conditions of the Creative Commons Attribution (CC BY) license (http:// creativecommons.org/licenses/by/4.0/). 